\title{
Pharmacognostic and elemental analysis of the rhizome of $C$. spectabilis (Fenzl) Schumann (Costaceae)
}

\author{
Salisu SHEHU ${ }^{1 *}$, Abdulmumin Z. ABUBAKAR ${ }^{1}$, Umar H. DANMALAM ${ }^{1}$, Najma ILYAS ${ }^{1}$ \\ and Nuhu M. DANJUMA ${ }^{2}$
}

${ }^{1}$ Department of Pharmacognosy and Drug Development, Ahmadu Bello University, Zaria. Nigeria.
${ }^{2}$ Department of Pharmacology and Therapeutics, Ahmadu Bello University, Zaria. Nigeria.

Received $18^{\text {th }}$ August 2020; Accepted $4^{\text {th }}$ December 2020

\begin{abstract}
The extract from the rhizome of Costus spectabilis (Costaceae) has been used to treat many illnesses including eye infections and cataract. The present study aimed to establish the pharmacognostic features of the rhizome by evaluating its macro-morphological characteristics, micro-morphological features using its anatomical section, physicochemical constants and elemental profile of its powder according to standard methods. Macro-morphology revealed features typical of a rhizome. Microscopical examination shows vascular bundles scattered throughout the ground tissue of starch-filled cellulosic parenchyma, parenchymatous cortex, endodermis and Oleoresin cells. Chemomicroscopy of the powder showed cellulosic cell walls, lignified cell walls, starch grains, fats and oil. The powder was found to have a moisture content of $12.3 \%$, Total ash of $4.3 \%$, acid insoluble ash of $2.0 \%$, water soluble ash of $1.2 \%$, water soluble extractive of $11.0 \%$ and alcohol soluble extractive of $6.5 \%$. Elemental analysis showed the presence of $\mathrm{Zn}, \mathrm{Cu}, \mathrm{Mg}$, $\mathrm{Fe}, \mathrm{Pb}, \mathrm{Ni}, \mathrm{Mn}$ and $\mathrm{Cd}$ at concentrations of 24.62, 2.63, 1449.21, 113.23, 36.50, 31.90, 86.93 and $1.23 \mathrm{mg} / \mathrm{kg}$ in the powder respectively. The study has established some pharmacognostic features and elemental composition of the rhizome of $C$. spectabilis. The information could serve useful in providing quality control parameters and standardization of the crude drug.
\end{abstract}

Keywords: Macro-morphology; Microscopical; Physico-chemical; Standardization; Elemental analysis

\section{INTRODUCTION}

In the past, authentication of medicinal plants depends on the experience of the traditional medicine practitioner, his knowledge acquired by trial and error to distinguish useful plants with beneficial effects from those that were toxic or inactive, and also which combinations or processing methods had to be used to gain consistent and optimal results [1]. This technique of evaluation is less reliable, as the sources of medicinal plants broadened, adulteration and or substitution become more common and Hence, the need for standardization. Standardization of herbal medicines is the process of prescribing a set of standards or inherent characteristics, constant parameters, definitive qualitative and quantitative values that carry an assurance of quality, efficacy, safety and reproducibility [1]. It is considered as an integral step of establishing correct identity of crude drugs. Thus, before any crude drug is included in herbal pharmacopoeia, its pharmacognostic as well as other standard parameters must be

*Correspondence. E-mail: shehus3621@yahoo.com Tel: +234-8134924454.

ISSN 0189-8442

2021. Published by Faculty of Pharmaceutical Sciences, University of Jos, Nigeria. Under Creative Commons Attribution-Non-Commercial 4.0 International License. https://creativecommons.org/licenses/by-nc/4.0/ 
established [2]. Determination of elemental profile of a crude drug is also an important aspect of standardization, because the therapeutic benefits or toxicities of many crude substances has been attributed to the presence and or level of some inorganic mineral elements. Thus, in order to ensure safety or explain therapeutic benefits of these crude drugs, there is a daring need to know about their elemental composition.

Costus spectabilis (Fenzl) Schumann is one of the species belonging to the family Costaceae. It is recognized by its four horizontally spreading leaves forming a cruciform rosette flat on the ground, with an inflorescence in the centre producing large yellow flowers. Its underground storage organs is rhizome and it is found over much of tropical Africa including Nigeria [3]. The plant is commonly called Yellow trumpet and 'Takalmin zomo' (in Hausa). The leaf and stem sap of the plant were used as eye drops to treat eye infections and as nose drops to cure headache, in frictions or a vapour bath to treat oedema and fever, or applied to treat urethral discharges, venereal diseases, jaundice and to prevent miscarriage. Rhizome pulp is applied to abscesses, ulcers and Guinea worm to mature them [4]. Also, previous report revealed that the fresh sap from the rhizome of Costus spectabilis or the water extract were used as eye drop in traditional medicine for the treatment of cataract [5]. Furthermore, the aqueous ethanol extract of the rhizome has been shown to ameliorate indices of lens opacity in an in-vitro experiment [6]. Despite its wide usage, information regarding the pharmacognostic standards and elemental profile of this crude drug is lacking. Hence, an attempt was made in this work to establish such parameters.

\section{EXPERIMENTAL METHODS}

Collection, identification and preparation of the plant material. The whole plant of Costus spectabilis (obtained from wild) was collected from Shika, Zaria, Kaduna State on September, 2018. The freshly collected plant material was identified by a taxonomist, Mal. U.S Gallah of Bioresources Unit, National Research Institute for Chemical Technology (NARICT) Basawa Zaria with a voucher No. 1611. The rhizome of the plant material was then collected, sliced and dried under the shade 14 days. The dried plant material was pulverized, weighed and packed in a plastic container.

Macroscopic evaluation of the rhizome. The rhizome of $C$. spectabilis was examined for macro-morphological features as described by the standard methods $[7,8]$.

Microscopical evaluation of the transverse section. The microscopical evaluation of the anatomical section and powdered sample of the rhizome of $C$. spectabilis was carried out using standard methods [9]. The evaluation was conducted by taking thin transverse sections of the rhizome of $C$. spectabilis. The sections were cleared with chloral hydrate solution and mounted in dilute glycerol. It was then observed under the microscope. Other thin sections were initially stained with Phloroglucinol and $\mathrm{HCl}, \mathrm{N} / 50$ iodine or Sudan red with gentle warming, mounted in glycerol and then observed under the microscope.

Chemo microscopical studies of powdered rhizome. The histochemical detection of cell wall materials and cell contents of the powdered rhizome such as cellulose, lignin, starch, suberins, tannins, calcium oxalate and calcium carbonate was carried out using standard methods [7,9].

Determination of physicochemical parameters. The powdered rhizome of $C$. spectabilis was evaluated for physicochemical parameters such as moisture content, total ash, acid insoluble ash, water soluble ash and solvent extractives according to standard methods [7].

Elemental analysis of the powdered rhizome of C. Spectabilis. The determination of elemental composition of the powdered 
rhizome of $C$. Spectabilis was carried out using atomic absorption spectroscopy (AAS). The procedure was performed following the method described by Rajurkar and Damame [10]. The elements evaluated include: zinc, copper, manganese, magnesium, iron, lead, nickel and cadmium.

\section{RESULTS AND DISCUSSION}

Morphological features. The rhizome of $C$. spectabilis is elongated, cylindrical in shape, $4-16 \mathrm{~cm}$ long and $0.3-1 \mathrm{~cm}$ diameter, It is covered by brownish, imbricate, membranous sheaths (Plate I). The rhizome also shows some features such node and internodes, which are typical of a rhizome (Plate I). The microscopic features of the transverse section of the unpeeled rhizomes shows the presence of an epidermis (which constitute the outer part), the cortex consisting of thin-walled parenchyma cells containing starch and oleoresin containing cells (Plate II-III). Some of the specie which are taxonomically related to $C$. spectabilis such as Zingiber officinale and Curcuma longa were reported to contain oleoresin cells. [11]. The blue coloration of the cell wall of epidermal and parenchyma cells upon staining with chlor-zinc iodine (Table 1), indicates the presence of true cellulose, the major chemical composition of the plant cell walls [9]. The vascular bundles are scattered throughout the stele and cortex, and an endodermis is evident, a special feature restricted to monocotyledonous rhizomes [12]. The absence of any well-developed column of xylem tissue in the form of a central wood confirms that the underground structure is a rhizome and not a root. The lignin present in the vascular tissues (Table 1) is an additional strengthening material commonly found in cell walls of tracheids, vessels, fibres and sclereids of vascular plants [9]. Examination and documentation of key anatomical features of the transverse sections of fresh plant materials is an accurate method of identification of ingredients of a polyherbal formulation [13].
The powdered rhizome of $C$. spectabilis was observed to be yellowish white in colour, with aromatic odour, and acrid taste. The chemomicroscopic examination of the powder revealed the composition of cell wall materials and cell inclusions as presented in Tab. 1. Some of these features are characteristic and could be useful in the identification of the powdered plant material.

Physicochemical parameters. The physicochemical parameters of powdered rhizome of C. spectabilis were determined based on the methods recommended by World Health Organization (WHO). As apparent from Table 2 , the percent weight loss on drying or moisture content value was found to be $12.30 \pm 0.12 \% \mathrm{w} / \mathrm{w}$. The less value of moisture content of drugs could prevent content bacterial, fungal or yeast growth through storage and it is recommended that the moisture content in crude drugs should not be more than $14 \%$ [14]. Since the value is below the maximum limit, it implies that the powder of this plant material can be stored for a longer period with lower chances of microbial attack and some other chemical reactions that may alter the nature of its active constituent. The ash values; total ash, acid insoluble ash and water soluble ash values, which were found to be $4.00 \pm 0.1 \%, 2.00 \pm 0.13 \%$ and $1.20 \pm 0.07 \%$ respectively (Table 2) could serve as quantitative standards that gives an idea on quality, authenticity and purity of the powdered crude drug [15]. The water extractive value $(11.00 \pm 0.19 \% \mathrm{w} / \mathrm{w})$ is higher compared to alcohol extractive $(6.50 \pm 0.08 \%$ $\mathrm{w} / \mathrm{w}$ ) (Table 2). This signifies that the plant material may likely contain high proportion of more water-soluble constituents such as glycosides. The sugars present in the glycosides confers greater solubility of glycosides in water than alcohol. Extractive values are used as valuable tools in estimating the chemical constituents present in a crude drug and in the evaluation of definite 
constituents soluble in a particular solvent [16].

Elemental profile. The elemental analysis of the powdered rhizome of $C$. spectabilis revealed that it contains some important mineral elements ( $\mathrm{Zn}, \mathrm{Cu}, \mathrm{Mg}, \mathrm{Fe}, \mathrm{Pb}, \mathrm{Ni}, \mathrm{Mn}$ and $\mathrm{Cd}$ ) with their various concentrations (Tab. $3)$. The plant material has magnesium $(\mathrm{Mg})$ ion being of the highest concentration (1449.21 $\mathrm{mg} / \mathrm{kg}$ ). Magnesium is regarded as one of the most important cation in the body. It acts as a cofactor for more than 350 enzymes particularly those associated with energy metabolism. Disturbances of magnesium homeostasis adversely affect the cellular functions and may lead to pathological conditions [17]. The high content of magnesium of the plant material may likely contributes to the observed anticataract effect of $C$. spectabilis. It was previously reported that administration of $200 \mathrm{mg} / \mathrm{l}$ magnesium in water delayed progression of cataract in Shumiya cataract rats, a rodent model of human senile cataract [18]. Furthermore, It has been established that rats fed on $30 \%$ galactose diet with oral or topical magnesium taurate showed tendency towards restoration of lens calcium/magnesium ratio and reduced oxidative stress compared to vehicle treated groups [19]. An in vitro anticataract study also showed that addition of magnesium taurate to the medium containing $30 \%$ galactose reduces cataract progression [19]. The presence of Zinc $(24.62 \mathrm{mg} / \mathrm{Kg})$ may also support cataract ameliorative effect of $C$. spectabilis. Some studies have shown that some minerals including zinc serve as co-factors for naturally occurring antioxidant enzymes such as SOD and the plasma levels of zinc were found to be significantly low in cataractous patients [20]. Topical application of Zinc sulphate has been shown to retard opacities progression and lowered opacity score in selenite-induced cataract in rabbits [21]. Iron $(113.23 \mathrm{mg} / \mathrm{Kg})$ is an essential component of respiratory pigments haemoglobin and myoglobin and also of various enzyme systems in the body. The study revealed a high concentration of nickel (Ni) (Table 3). Although it may be beneficial as it can activate some enzyme systems, nickel toxicity at higher levels is possible. However, its toxicity is not very common in humans because nickel absorption is very low [22]. A deficiency of manganese causes diseases and an excess causes poisoning of the central nervous system[23]. The study revealed high levels of manganese in the plant material compared to the recommended permissible limit[24]. Lead $(\mathrm{Pb})$ is nonessential trace element having functions neither in human's body nor in plants. Exposure to lead $(\mathrm{Pb})$ may cause an adverse effect on the body [25]. The study revealed that lead $(\mathrm{Pb})$ concentration in the plant material is much higher than the permissible limit of 0.43 mgKg-1 [25]. Cadmium (Cd) is another nonessential mineral found in the plant. Its concentration in the plant material is 1.23 mgKg-1 higher than the permissible limit of $0.21 \mathrm{mgKg}-1$. However, its toxic effects have been observed in man from the regular consumption of plants in excess of $3 \mu \mathrm{g} \mathrm{g}^{-1}$ [26].

Throughout the world, there is an increasing interest in the importance of dietary minerals in the prevention of several diseases [27]. Therefore, full understanding of the amount and type of elements found in medicinal plants could help to minimize the risk of adverse effects to consumers.

Conclusion. The current study has established the presence of some pharmacognostic features and elemental composition of the rhizome of C. spectabilis. The information could serve useful as a monograph in the identification and standardization of the plant. 
S. Shehu et al. / J. Pharmacy \& Bioresources 18(1), 25-31 (2021)

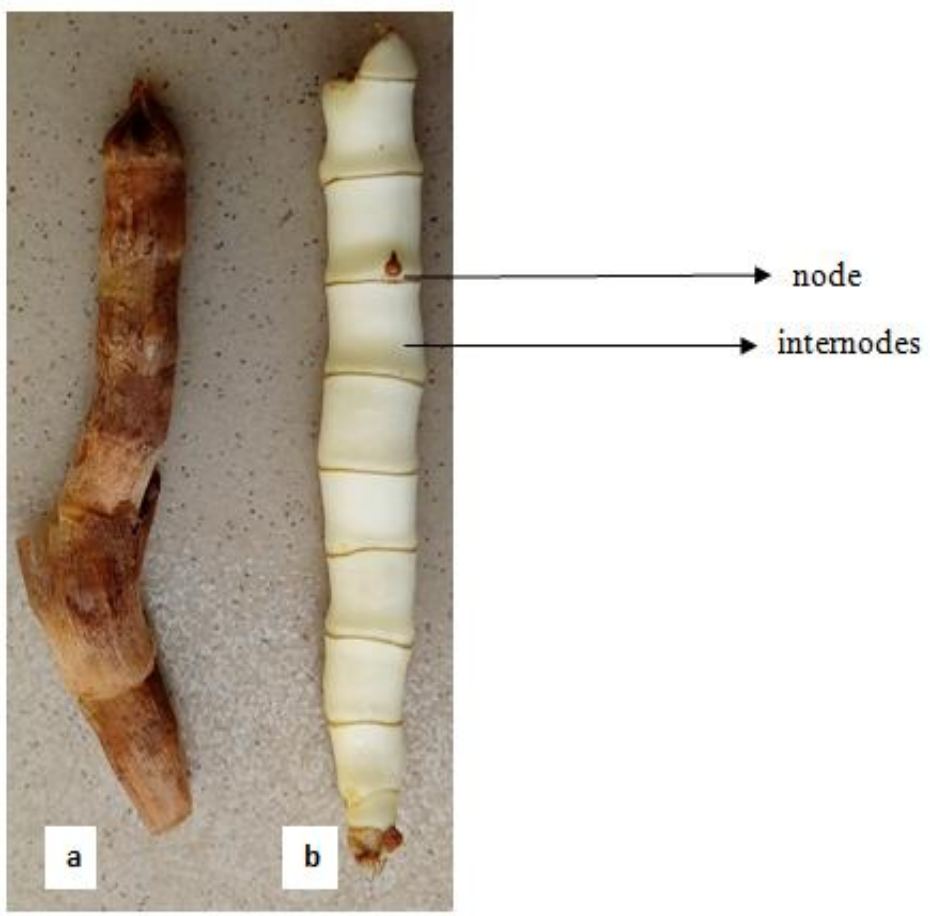

Plate I: Photograph of the unpeeled (a) and peeled (b) rhizome of $C$. spectabilis

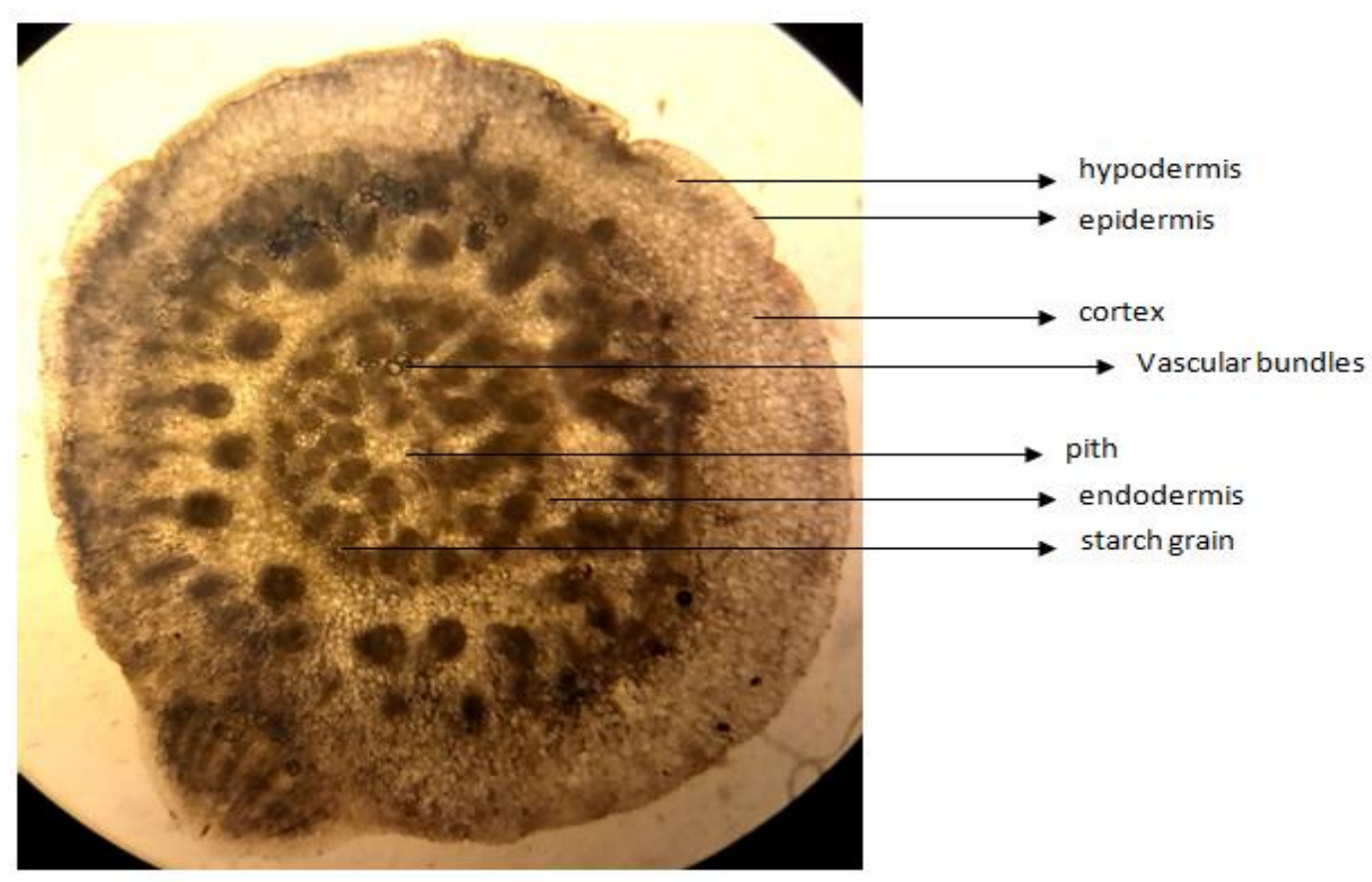

Plate II: Photomicrograph of the Transverse Section of C. spectabilis rhizome (Magnification×64) 


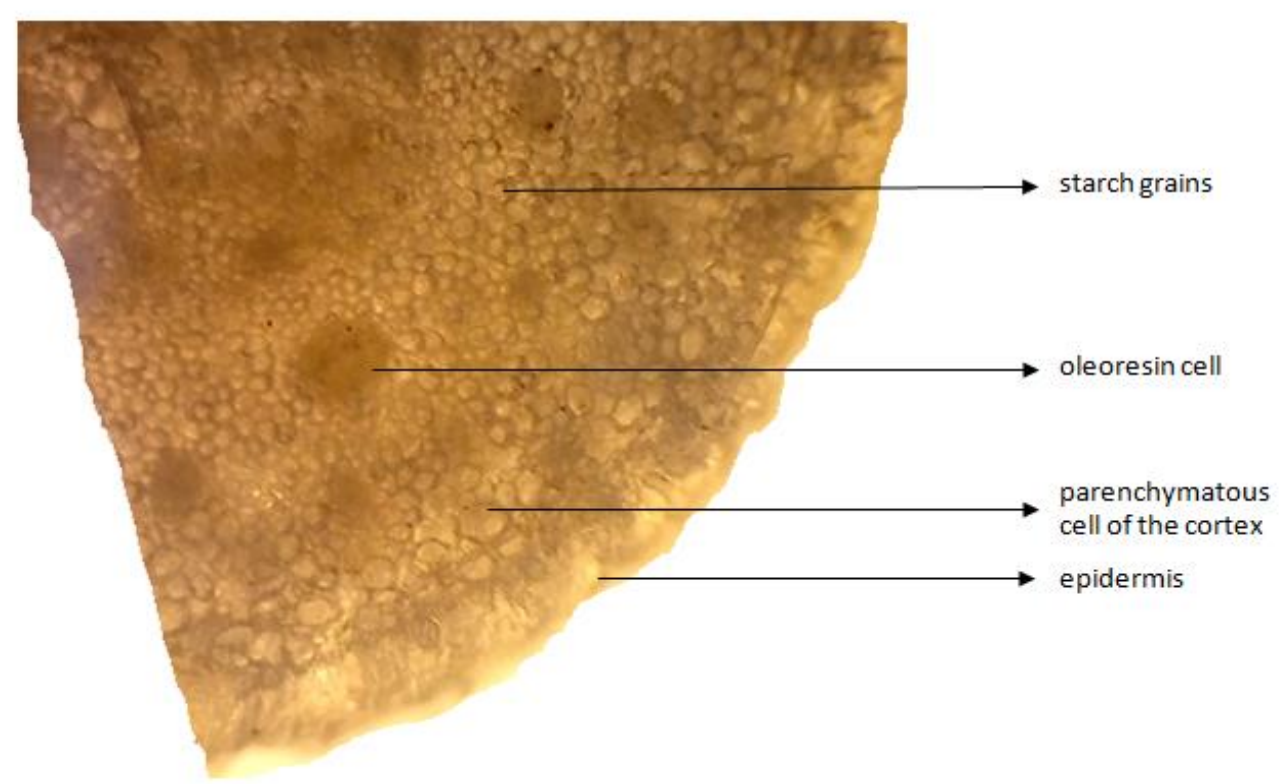

Plate III: Photomicrograph of the transverse section of the rhizome C. spectabilis showing some features (Magnification $\times 160$ )

Table 1: Chemo Microscopic Features of the Powdered Rhizome of C. Spectabilis

\begin{tabular}{lll}
\hline Constituent & Observation & Inference \\
\hline Cellulose & blue coloration of the cell walls of epidermal and parenchyma cells & Present \\
Lignin & cherry-pink colour around the vascular bundles & Present \\
Starch & Starch grains in some parenchyma cells turns to blue black & Present \\
Fats and oil & The oleoresin cells becomes red in colour & Present \\
Tannins & Some of the cells turns to dark blue & Present \\
\hline
\end{tabular}

Tab. 2: Physicochemical Constants of Powdered Rhizome of C. Spectabilis

\begin{tabular}{ll}
\hline Physicochemical parameter & Values $(\% \mathrm{w} / \mathrm{w})^{*}$ \\
\hline Total Ash Value & $4.00 \pm 0.10$ \\
Acid Insoluble Ash Value & $2.00 \pm 0.13$ \\
Water Soluble Ash Value & $1.20 \pm 0.07$ \\
Alcohol soluble extractive & $6.50 \pm 0.08$ \\
Water soluble extractives & $11.00 \pm 0.19$ \\
Moisture Content (loss on Drying) & $12.30 \pm 0.12$ \\
\hline
\end{tabular}

*Average of three determinations

Tab. 3: Elemental Composition of the Powdered Rhizome of C. spectabilis

\begin{tabular}{lcc} 
Element & Concentration $(\mathrm{ppm})$ & "Permissible limit $(\mathrm{ppm})$ \\
\hline Iron & 113.23 & 20.00 \\
Magnesium & 1449.21 & 2000 \\
Zinc & 24.62 & 27.40 \\
Cupper & 2.63 & 3.00 \\
Lead & 36.50 & 0.43 \\
Nickel & 31.90 & 1.63 \\
Cadmium & 1.23 & 0.21 \\
Manganese & $86.93 \quad 2.00$ \\
\hline \multicolumn{2}{c}{${ }^{*}[24]$} &
\end{tabular}




\section{REFERENCES}

1. Kunle O.F., Egharevba H.O. and Ahmadu P.O. (2012). Standardization of herbal medicines - A review. International Journal of Biodiversity and Conservation 4(3), 101-112.

2. Abere T. A., Onwukaeme D. N. and Eboka C.J. (2007). Pharmacognostic evaluation of the leaves of Mitracarpus scaber Zucc (Rubiaceae). Tropical Journal of Pharmaceutical Research, 6 (4):849-853.

3. Maas-van de Kamer H., Maas P.J.M., Wieringa J.J. and Specht C.D. (2016). Monograph of African Costaceae. Blumea, $61: 280-318$.

4. Aweke, G.,(2007) Costus afer Ker Gawl.[Internet] Record from PROTA4U. Schmelzer, G.H. and Gurib - Fakim A. (Editors). PROTA (Plant Resources of Tropical Africa/ Ressources végétalesde l'Afrique tropicale), Wageningen, Netherlands. <http://www.prota4u.org /search.asp>. Accessed 7 December 2016.

5. Shehu S. and Dauda B. (2018). Inventory of Medicinal Plants used in the Treatment of Eye Ailments in Zaria Metropolis, Kaduna State, Nigeria. Nig. J. Pharm. Sci. 17(1):68-75.

6. Shehu S., Umar F. S., Shehu S., Danmalam U. H. and Danjuma N. M. (2019). Extract of Costus spectabilis Attenuates $\mathrm{H}_{2} \mathrm{O}_{2}$-Induced Cataract In Cultured Rat Lenses. Tropical Journal of Natural Product Research; 3(4):145148.

7. World Health Organization (2011): Quality control Method for Herbal Materials, p 9-31.

8. Sumitra C. (2014). Importance of pharmacognostic study of medicinal plants: an overview. J. Pharmacogn Phytochem; 2(5): 69-73.

9. Evans, W. C. (2009): Trease and Evans pharmocognosy. Elsevier. Pp. $10-11$

10. Rajurkar N.S. and Damame M.M. (1997). Elemental analysis of some herbal plants used in the treatment of cardiovascular diseases by AAS and NAA. $J$ Radioanalytical Nucl Chem; 219 (1):77-80.

11. Abraham A., Samuel S. and Mathew L. (2017). Pharmacognostic Evaluation of Curcuma longa L. Rhizome and Standardization of its Formulation by HPLC Using Curcumin as Marker. International Journal of Pharmacognosy and Phytochemical Research 10(1); 3842.

12. Alamgir A.N.M. (2017). Therapeutic Use of Medicinal Plants and Their Extracts: Springer International Publishing, Switzerland. pp 283.

13. Hetal J., Jayanta K. M. and Ashish V. (2017). Standardization of anticonvulsant polyherbal formulation by pharmacognostical, DNA fingerprinting and highperformance thin layer chromatography combined with chemometrics. Int. J. Curr Pharm Res, 9 (1), 50-58.

14. Pandey M. K., Singh G. N., Sharma R. K. and Sneh L. (2012). Standardization of Yakrit Plihantak Churna: An Ayurvedic Poly herbal formulation, International Journal of Pharmaceutical Sciences and Research, 3 (1), 171- 176.
15. Swamy, P., and Kamil S.M. (2010). Preliminary Pharmacognostical and Phytochemical Evaluation of Portulaca quadrifida Linn", International Journal of Pharm. Tech. Research, Vol. 2,No. 3, 1699-1702.

16. Shwetajain C., Sharma P., Khatri A. and Ankur V. (2011). Pharmacognostic and Phytochemical Investigations of the Leaves of Zizyphus xylopyrus (Retz) Wild. International Journal of Pharmacy and Pharmaceutical Sciences, 3(2), 122-125.

17. Agarwal R., lgor I., and Puneet A. (2014). Pathogenetic role of magnesium deficiency in ophthalmic diseases. Biometals, 27:5-18.

18. Nagai N., Ito Y., Inomata M., Shumiya S., Tai H., Hataguchi Y. and Nakagawa K. (2006). Delay of cataract development in the Shumiya cataract rat by the administration of drinking water containing high concentration of magnesium ion. Biol Pharm Bull, 29(6):1234-1238.

19. Agarwal R., Iezhitsa I. N., Agarwal P., Spasov A. A. (2013). Mechanisms of cataractogenesis in the presence of magnesium deficiency. Magnes Res. 26(1):2-8.

20. Gupta S.K., Selvan V.K., Agrawal S.S. and Saxena R. S. (2009). Advances in Pharmacological Strategies for Prevention of Cataract Development. Eye Journal. 23:1016.

21. Baha'a A. and Alzubaidy A.A. (2014). Role of Topicallyapplied Zinc sulphate in the prevention of Selenite-induced Cataract in Rabbits. Int. J. Adv. Res. 2, 1014-1022.

22. Divrikli U., Horzum N., Soylak M., Elci L. (2006). Trace heavy metal contents of some spices and herbal plants from Western Anatolia, Turkey. International Journal of Food Science and Technology, Oxford, 41(6) p. 712-716.

23. Mekassa B. and Chandravanshi B. S. (2015). Levels of selected essential and non-essential metals in seeds of korarima (Aframomum corrorima) cultivated in Ethiopia. Brazilian Journal of Food Technology. Campinas, 18 (2), p. 102-111.

24. Food and Agriculture Organization of United Nations FAO;World Health Organization-WHO. Format of codex commodity standards. In: Food And Agriculture Organization of United Nations - FAO; World Health Organization - WHO (1984). Codex alimentarius commission: procedural manual. Rome: FAO/ WHO, p. 4349. (v. XVII).

25. Johnson F. M. (1998). The genetic effects of environmental lead. Mutation Research-Reviews in Mutation Research; 410 (2) : 123-140.

26. Ajasa A. M.O., Bello M.O., Ibrahim A.O., Ogunwande I.A. and Olawore N.O., (2004). Heavy trace metals and macronutrients status in herbal plants of Nigeria. Food Chemistry, London, 85, (1) : 67-71.

27. Saraf A. and Samant A. (2013). Evaluation of some minerals and trace elements in Achyranthe saspera Linn. International Journal of Pharmaceutical Sciences. 3(3): 229- 233. 